\title{
Assessing Carbon Awareness of Indonesian Mining and Oil \& Gas Companies
}

\author{
Paulina Permatasari ${ }^{1}$, Vania Natasha ${ }^{2}$, Laura Angelica ${ }^{3}$ \\ \{paulina@ unpar.ac.id ${ }^{1}$, assdirteam1.hanielshengroup@gmail.com ${ }^{2}$, \\ assdirteam9.hanielshengroup@gmail.com ${ }^{3}$ \} \\ Parahyangan Catholic University ${ }^{1}$, Parahyangan Catholic University ${ }^{2}$, Parahyangan Catholic \\ University $^{3}$
}

\begin{abstract}
The issue of air pollution has become one of the trending topics in Indonesia, mainly related to greenhouse gas emissions produced by companies. This study aims to analyse how companies in Indonesia disclose their carbon emission disclosures in their sustainability reports, including making assessments related to company performance on carbon emissions. This research was conducted using descriptive methods and content analysis to generate a structured and systematic analysis. This study used secondary data sources in the form of 33 sustainability reports published by 11 Indonesian companies in the Mining and Mineral and Oil and Gas industries in 2016-2018. The results of the research show that Mining and Mineral and Oil and Gas companies in Indonesia during 2016-2018 period have good performance in relation to carbon emissions, both in terms of disclosure in its sustainability report and in terms of the performance of related companies' efforts to reduce carbon emissions.
\end{abstract}

Keywords: Carbon Emission, Carbon Emission Disclosure, GRI

\section{Introduction}

In recent years, one issue experiencing urgency in Indonesia is the issue of air pollution. In July 2019, Jakarta had an Air Quality Index (AQI) figure of 195. The index indicated that Jakarta was in an unhealthy air condition. In order, Jakarta occupies the first position with the highest AQI level, followed by Dubai, Johannesbug, Beijing, and Santiago [1]. The emergence of this news made people uneasy, as air pollution is correlated with several diseases such as acute respiratory infections (ARI), coronary heart disease, pneumonia, chronic obstructive pulmonary disease (COPD/COPD), and asthma. According to research from Universities Indonesia, almost 60 percent of patients in Jakarta hospitals suffer from diseases caused by air pollution [2]. Director of the Committee for the Elimination of Lead in Gasoline (KPBB), Ahmad Safrudin, said that after being calculated, the loss of funds to treat diseases caused by unhealthy air in Jakarta could reach Rp 51.2 Trillion [3].

Some of the main sources of air pollution include inefficient modes of transportation, household fuel and waste burning, as well as coal-fired power plants and industrial activities. The Indonesian Forum for the Environment (Walhi) and the Governor of DKI Jakarta, Anies Baswedan, agreed that one of the biggest contributors to air pollution in Jakarta is coal-fired steam power plants (PLTU), with a value of 20-30 percent of the total air pollution in Jakarta [4]. Until May 2018, air pollution from coal-fired power plants in Southeast Asia has contributed to 20,000 premature deaths annually. If the plans for the 
development of various new power plants continue to run, the early death rate is expected to continue to rise until it reaches 70,000 [5] [6]. In other words, mining companies that extract raw materials as fuel for PLTU also have a significant contribution to the air pollution that is currently happening.

To be able to successfully make an ideal sustainability report, a company must be able to describe the contents of all its activities in a complete and in-depth manner. However, making this will be difficult if the company does not know the priorities of the stakeholders. Therefore, choosing the most ideal sustainability reporting reference is needed by the company. In issues related to air pollution and carbon emissions, one of the main references that can be used as a guide for companies in disclosing sustainability reporting is GRI. With the existence of GRI, it is hoped that companies, especially those involved in Mining and Mineral and Oil \& Gas sectors, have a basis for measuring performance related to carbon emissions.

Based on the background of the study, this study specifically focuses on assessing companies' performance in relation to carbon emissions during the 2016-2018 period.

\section{Literature Review}

\subsection{Climate Change}

The earth is experiencing occurrences of global warming as the impact of climate change. It can be noticed by dynamic weather and climate episodes that keeps changing from time to time [7].

The First World Climate Conference, organized in Geneva, Switzerland in 1979, highlighted the problem of global warming as an international priority. Scientists, politicians and economic leaders questioned the reality of the impact of human activities on the climate. This led to an awareness of the need to limit the rise of the Earth's temperatures within an acceptable cap for future generations [8].

Climate change is a threat to a stable function of the Earth's system, and ecosystem plays critical roles in mitigation and adaption to climate change. According to the UNFCC: "Climate change is a change of climate which is attributed directly or indirectly to human activity that alters the composition of the global atmosphere and which is in addition to natural climate variability over comparable time periods". Climate change which resulted from increased greenhouse gases (GHGs) in the atmosphere, is the greatest social, economic and environmental threat of this century [9].

According to Ja'far and Kartikasari [10], economic activities are also one of the triggers of global warming. Industry growth will have a positive correlation with an increased emission from companies' operational activities. Although some companies claim the products that they produce are environmentally friendly, they have not provided sufficient explanations regarding their efforts to reduce the impact of environmental damage [11].

\subsection{Carbon Emission}

Carbon emission is a release of carbon into the Earth's atmosphere. The release occurs due to a combustion of carbon, whether in singular or compound [12].

$\mathrm{CO}_{2}$ emissions continuously increase from time to time at global, regional, and national levels whether in a country or a regional location. This happens because of the increased use of energy from organic materials (fossil), changes in land use and forest fires, and also an 
increase in anthropogenic activities. One of the biggest contributors of carbon emissions is companies' operational activities. In dealing with climate change, companies are expected to be able to disclose their activities related to climate change improvement, one of which is by making carbon emission disclosure [11].

A case study by Hashim, et al. [13] focusing on the plating industry, illuminated that electricity consumption accounts for the highest amount of carbon emission within the plating process. Substantial emission reduction, of around $20 \%$, could be achieved by the implementation of higher efficiency heating tools that require less energy, and also produce better heating performance for the process. Ultimately, by reducing carbon emissions, the industry can ensure cleaner production across the entire plating process [13].

\subsection{Carbon Emission Disclosure}

Carbon emission disclosures has become more significant because investors are increasingly taking note of carbon profiles in their evaluation of asset prices and potential investments. In response, companies are learning to report their carbon management initiatives, some going so far as to track $\mathrm{CO}_{2}$ emissions through the value chain at the product level and disclose this information on consumer product labels [14].

Stakeholders have a significant role in carbon emission disclosure, because in protecting the environment and company's sustainability, many parties are needed to supervise. Stakeholders expect companies to calculate and report the emissions produced by the company, because carbon management and its reporting are used to manage and assess business risks and business opportunities related to climate change [15]. If a company is able to manage climate change risks, then the company can avoid disasters caused by global warming. Companies which produce environmental disclosures could increase their legitimacy in the society because they are known to be responsible to the environment [16].

Berthelot and Robert [17] also stated that companies that disclose carbon emissions have advantages to gain legitimacy from stakeholders and avoid corporate threats resulting from greenhouse gas, such as increased operating costs, declining demand, reputation risks, legal process, fines, and penalties [16].

Another study in Europe suggests that external stakeholder pressure is a determinant of the existence of emissions disclosure, but not in terms of completeness. This finding is consistent with the stakeholder theory, which argues that companies respond to external stakeholder pressure to report greenhouse gas emissions, but also with legitimacy theory, which claims that firms can use carbon disclosure to address legitimacy exposures [18].

\subsection{Carbon Accounting}

The implication of the Kyoto Protocol was the emergence of carbon accounting, which is a necessity for companies to recognize, measure, record, present and disclose their carbon emissions [19]. Carbon accounting is an accounting method carried out to measure the amount of carbon dioxide that will not be released into the air as a result of the company's flexible mechanism, as a form of organizational compliance to the Kyoto Protocol [20].

By implementing carbon accounting, a company can measure the level of carbon emission produced by the company, then the management can establish strategies to reduce the carbon emission and report it to the company's stakeholders [21].

A fully functioning carbon accounting system needs to be based on measurement techniques that are: materially accurate, that is, they need to reflect actual atmospheric emissions; consistent over space and time through the use of calibrated equipment, agreed 
procedures and verification; and incorporate indicators of certainty to allow for valid interpretation of data [14].

The design of carbon management accounting can be of strategic importance for companies trying to measure and manage their carbon performance. Managers may expect that carbon management accounting helps them identify and assess the potentials of different activities to reduce the company's emissions and related economic impacts [22].

\section{Methods}

This research was conducted to analyse the performance of Indonesian companies in Mining and Mineral with Oil and Gas industries during the 2016-2018 period. In Indonesia, there are a total of 15 Indonesian companies in the industry that have published sustainability reports. However, the sample used in this study consisted of only 11 companies. This is because there have been only 11 companies that have published complete, regular and public sustainability reports from 2016-2018. This includes PT Aneka Tambang Tbk, PT Bukit Asam Tbk, PT Bumi Resources Tbk, PT Indo Tambangraya Megah Tbk, PT Petrosea Tbk, PT Vale Indonesia Tbk, PT Badak LNG, PT Pertamina, PT Pertamina EP Cepu, PT Pertamina Geothermal Energy, and PT Perusahaan Gas Negara Tbk.

Conducting research is one of the various methods used to find a solution for a particular problem, under a comprehensive framework with the inclusion of existing situational factors. In carrying out research, certain methods are needed to ensure that the research process is able to run systematically and in an organized manner. The selection of appropriate research methods helps in identifying a problem, collecting and analysing data, as well as elaborating a valid conclusion from all the collected data [25].

The research method used in this study is a combination of descriptive method and content analysis. Descriptive method has proven its usefulness in providing an overview of relevant aspects from various perspectives, such as an individual, an organisation or industry orientation. Content analysis is a technique to collect and analyse specific contents [26]. The word content itself can refer to various elements, such as words, meanings, images, symbols, ideas, themes, or messages communicated. In other word, content analysis is a data collection technique which consequently converts qualitative data to a quantitative format through the process of codification [27].

Therefore, both methods used in this study is considered sufficient to analyse the performances of Indonesian companies in the Mining and Mineral and Oil and Gas industries during 2016-2018.

\section{Result and Discussion}

\subsection{GRI Approach for Measuring Companies' Performance on Carbon Emission}

In this study, other aspects outside of emissions, such as energy, general disclosures, and economic performances are also analysed. This is because these three aspects have an indirect connection to the measurement of a company's carbon emission performances.

Carbon emissions produced by companies must always be adequately managed and regularly monitored by companies, to ensure that the amount of emissions produced does not exceed the reasonable threshold determined by governments. By using the indicators of the 
general disclosure aspects above, they can become one of the basis for measuring a company's carbon emission performances, as a form of responsibility and monitoring mechanism for the carbon emissions produced.

In addition, it also becomes important for a company to assess the impact of climate change. This is because one of the factors which causes climate change is the carbon emissions produced by companies. With the occurrence of climate change, companies are expected to be able to measure the financial impacts, risks and opportunities materialising around the company's environment.

\subsection{Assessing Companies' Performance on Carbon Emission}

\subsubsection{Percentage of Carbon Emission Disclosures Per GRI Indicators}

In measuring the percentage of a company's carbon emission disclosures, this study utilised 11 GRI indicators as the basis for measurement. A total of 11 sample companies were used as research objects, in which all companies regularly published their sustainability reports during 2016-2018.

Disclosure percentage measurement was done by counting the number of companies who periodically published carbon emission disclosures based on GRI indicators within their sustainability reports. The number of disclosures implemented in each period was then divided by the total amount of ideal disclosures from each period. In this study, two period timelines were measured: per annual year and per 3 years.

Table 1 presents the percentage of carbon emission disclosures per each GRI indicators produced by companies:

Table 1. Percentage of the Usage of Carbon Emission Disclosures Per GRI Indicators

\begin{tabular}{|c|c|c|c|c|c|c|c|c|c|c|}
\hline \multirow{2}{*}{ Aspect } & \multirow{2}{*}{$\begin{array}{c}\text { GRI } \\
\text { Standards }\end{array}$} & \multirow{2}{*}{$\begin{array}{c}\text { G4 } \\
\text { Guidelines }\end{array}$} & \multicolumn{4}{|c|}{ Amount } & \multicolumn{4}{|c|}{$\%$} \\
\hline & & & 1 & 2 & 3 & $\mathrm{~T}$ & 1 & 2 & 3 & $\mathrm{~T}$ \\
\hline \multirow{6}{*}{ Emission } & $305-1$ & G4-EN15 & 8 & 8 & 8 & $\begin{array}{l}2 \\
4\end{array}$ & $\begin{array}{r}72 \\
7\end{array}$ & $\begin{array}{c}72 . \\
7\end{array}$ & $\begin{array}{c}72 . \\
7\end{array}$ & $\begin{array}{c}72 . \\
7\end{array}$ \\
\hline & $305-2$ & G4-EN16 & 3 & 3 & 5 & $\begin{array}{l}1 \\
1\end{array}$ & $\begin{array}{c}27 \\
3\end{array}$ & $\begin{array}{c}27 . \\
3\end{array}$ & $\begin{array}{c}45 . \\
5\end{array}$ & $\begin{array}{c}33 . \\
3\end{array}$ \\
\hline & $305-3$ & G4-EN17 & 3 & 3 & 2 & 8 & $\begin{array}{c}27 \\
3\end{array}$ & $\begin{array}{c}27 . \\
3\end{array}$ & $\begin{array}{c}18 . \\
2\end{array}$ & $\begin{array}{c}24 . \\
2\end{array}$ \\
\hline & $305-4$ & G4-EN18 & 4 & 7 & 6 & $\begin{array}{l}1 \\
7\end{array}$ & $\begin{array}{c}36 \\
4\end{array}$ & $\begin{array}{c}63 . \\
6\end{array}$ & $\begin{array}{c}54 . \\
5\end{array}$ & $\begin{array}{c}51 . \\
5\end{array}$ \\
\hline & $305-5$ & G4-EN19 & $\begin{array}{l}1 \\
1\end{array}$ & 11 & 11 & $\begin{array}{l}3 \\
3\end{array}$ & $\begin{array}{c}10 \\
0\end{array}$ & $\begin{array}{c}10 \\
0\end{array}$ & $\begin{array}{c}10 \\
0\end{array}$ & $\begin{array}{c}10 \\
0\end{array}$ \\
\hline & $305-6$ & G4-EN20 & 1 & 2 & 3 & 6 & $\begin{array}{c}9.0 \\
9\end{array}$ & $\begin{array}{c}18 . \\
2\end{array}$ & $\begin{array}{c}27 \\
3\end{array}$ & $\begin{array}{c}18 . \\
2\end{array}$ \\
\hline \multirow{2}{*}{ Energy } & $302-1$ & G4-EN3 & 1 & 11 & 11 & 3 & 10 & 10 & 10 & 10 \\
\hline & $302-2$ & G4-EN4 & 0 & 0 & 0 & 0 & 0 & 0 & 0 & 0 \\
\hline \multirow{2}{*}{$\begin{array}{l}\text { General } \\
\text { Disclosure }\end{array}$} & $102-20$ & G4-36 & 6 & 8 & 7 & $\begin{array}{l}2 \\
1\end{array}$ & $\begin{array}{r}54 \\
5\end{array}$ & $\begin{array}{c}72 . \\
7\end{array}$ & $\begin{array}{c}63 . \\
6\end{array}$ & $\begin{array}{c}63 . \\
6\end{array}$ \\
\hline & $102-30$ & G4-46 & 8 & 8 & 9 & $\begin{array}{l}2 \\
5\end{array}$ & $\begin{array}{c}72 \\
7\end{array}$ & $\begin{array}{c}72 . \\
7\end{array}$ & $\begin{array}{c}81 . \\
8\end{array}$ & $\begin{array}{c}75 . \\
8\end{array}$ \\
\hline $\begin{array}{l}\text { Economic } \\
\text { Performanc } \\
\mathrm{e}\end{array}$ & $201-2$ & G4-EC2 & 4 & 4 & 4 & $\begin{array}{l}1 \\
2\end{array}$ & $\begin{array}{r}36 \\
4\end{array}$ & $\begin{array}{c}36 . \\
4\end{array}$ & $\begin{array}{c}36 . \\
4\end{array}$ & $\begin{array}{c}36 . \\
4\end{array}$ \\
\hline
\end{tabular}


Note:

$1=2016,2=2017,3=2018, \mathrm{~T}=$ Total

305-1 = Direct (Scope 1) GHG emissions; 305-2 = Energy indirect (Scope 2) GHG emissions; 305-3 = other indirect (Scope 3) GHG emissions; 305-4 = GHG emissions intensity; 305-5 = Reduction of GHG emissions 305-6 = Emissions of ozone-depleting substances (ODS); 302-1 = Energy consumption within the organization; 302-2 = Energy consumption outside of the organization; 102-20 = Executivelevel responsibility for economic, environmental, and social topics; $102-30=$ Effectiveness of risk management processes; 201-2 = Financial implications and other risks and opportunities due to climate change

For the purpose of simplification, Figure 1 an illustration related to the trends of GRI carbon emission indicator disclosures produced by companies within the last 3 years.

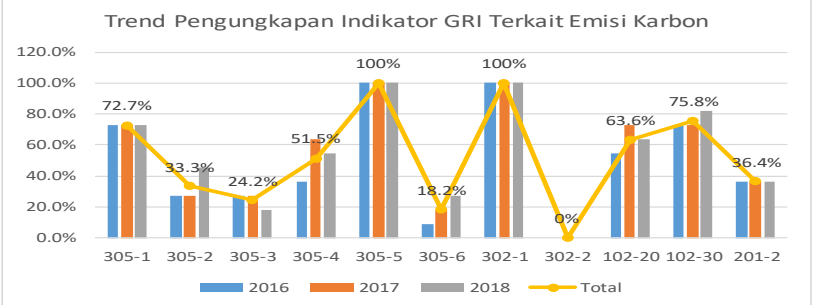

Figure 1. Trends of GRI Indicator Disclosures on Carbon Emissions

Based on Figure 1, one interesting notion is the fact that the GRI standard indicator 3022, or G4 Guideline indicator G4-EN4, has not been disclosed by any of the 11 company samples during the 3-year period. The GRI standard indicator, or G4 302-2 Guideline indicator G4-EN4 itself is an indicator which discloses the energy consumptions outside the organisation. The absence of this disclosure within the last 3 years may be caused by the difficulty in obtaining data related to this matter. However, the indicator is actually still correlated to a company's own carbon emissions, especially in regards to Carbon Emissions Scope 3, which comes from sources not owned or controlled by the company (for example, official travel done by the company). With the inclusion of this disclosure indicator, it will facilitate companies to calculate and analyse Carbon Emissions Scope 3, such as the aforementioned official travel done by companies using vehicles from parties outside of the organisation.

\subsubsection{Trend of Companies' Performance on Carbon Emission}

On the topic of carbon emissions, each company possess their own unique performance trends. In this study, company performance trends related to carbon emissions in the last 3 years $(2016,2017,2018)$ were measured by adding up the number of carbon emissions generated within Scope 1, Scope 2, and Scope 3 by each company. Emission figures included in this calculation are figures that have only been reported by companies openly and routinely for 3 consecutive years. Based on these criteria, Scope 1 emissions contained only 6 out of 11 companies which reported emissions figures openly and regularly for 3 consecutive years. For Scope 2 emissions, only 4 companies did so, while only two companies disclosed their Scope 3 emissions. The limitation of this disclosure can be caused by various elements, such as the limitation of a company's measurement methods, as well as the absence of emissions produced by the company within that scope. 
Table 2 shows the companies' carbon emission trends in tonnes of $\mathrm{CO}_{2}$ eq:

Table 2. Carbon Emission Trends for Scope 1,2 and 3

\begin{tabular}{cccc}
\hline & $\mathbf{2 0 1 6}$ & $\mathbf{2 0 1 7}$ & $\mathbf{2 0 1 8}$ \\
\hline Scope 1 & $22,234,139.15$ & $20,780,973.20$ & $19,212,018.87$ \\
Scope 2 & $220,696.43$ & $127,307.41$ & $162,542.15$ \\
Scope 3 & $4,429.93$ & $3,714.46$ & $4,006.64$ \\
\hline
\end{tabular}

From Table 2, it can be seen that the number of Scope 1 emissions have experienced a declining trend in the last 3 years. The emission reduction illustrates that companies in general have succeeded in carrying out emission efficiencies in the sector quite well. For Scope 2 and Scope 3 emissions, the trends show minute fluctuations, where it decreased during 2016 to 2017, but showed an increase during 2018. However, the incremental increase of emission levels during 2018 is still smaller compared to the decrease of emission levels during 20162017. This means that the increase of emissions during 2018 cannot be considered as monumentally significant. Therefore, it is still very possible for companies supress their numbers of Scope 2 and Scope 3 emission levels during the next period, by tightening the supervision of air emissions produced by the company.

A company's energy consumption can occur under two scopes, namely within the organisation and outside of the organisation. In this study, the trend analysis conducted was only related to energy consumption within the organisation. This is due to the absence of companies who disclosed the energy consumption figures outside of their organisations within the 2016-2018 sustainability reports. In addition, the figures included in the graphic are combined figures for energy consumption from renewable and non-renewable energy sources. This is because only 5 out of 8 companies listed their distribution of energy by sources. Additionally, the ratio of renewable and non-renewable energy sources was far too significant to compare.

Table 3 shows the companies' energy consumption trends in GJ units:

Table 3. Trends of Companies' Energy Consumption Levels

\begin{tabular}{ccc}
\hline $\mathbf{2 0 1 6}$ & $\mathbf{2 0 1 7}$ & $\mathbf{2 0 1 8}$ \\
\hline $5,550,656,105.88$ & $4,774,933,867.17$ & $4,704,402,986.69$ \\
\hline
\end{tabular}

It appears companies' energy consumption levels have decreased in the last 3 years. This illustrates that companies in general have succeeded in managing substantive energy efficiencies. With the decrease in energy consumption levels, it will also indirectly impact the emission reductions in both Scope 1 and Scope 2.

\subsubsection{Types of Carbon Emission' Levels}

Based on the results of the disclosure data, the highest type of carbon emissions in the last 3 years was $\mathrm{CO}_{2}$. In the disclosure of corporate sustainability, $\mathrm{CO}_{2}$ is categorised as Scope 1 emission indicator.

Based on the Republic of Indonesia's Presidential Regulation No. 71 of 2011, concerning the Management of National Greenhouse Gas Inventory, there are six types of gases classified as greenhouse gases, in which carbon dioxide $\left(\mathrm{CO}_{2}\right)$ is considered as one of the most 
important. Therefore, it is only normal that the results of this study found that $\mathrm{CO}_{2}$ had been the highest type of carbon emission disclosed in the last 3 years.

According to REPUBLIKA.co.id (2018), a study released by the Global Carbon Project found that there were 40.9 billion tons of carbon dioxide in the world during 2018, an increase from 39.8 billion tonnes during 2017. From the 11 sample companies, only 3 companies produced detailed disclosure of emissions for the division of emission categories. However, in 2018 one of the 3 companies did not publish their disclosures related to carbon emissions. This limited information makes it generally difficult to analyse trends in the research sample. However, if we look at the data from the other two companies, the $\mathrm{CO}_{2}$ emissions produced by both of them in 2018 were less than the emissions produced in 2017. This shows an opposite of the global $\mathrm{CO}_{2}$ emissions trend.

\subsubsection{Types of Carbon Emission with Low Awareness}

Based on the collected disclosure data, the types of carbon emissions that have not been given much attention by both the Mining and Mineral, and Oil and Gas companies in Indonesia in the last 3 years were related to ozone depleting substances (ODS).

According to the official government website of the Jambi Province, Web.jambiprov.go.id, ozone depleting substances (ODS) are chemical components that have the potential to react with ozone molecules within the stratosphere. The compound contains various combinations of chemical elements, such as chlorine, fluorine, bromine, carbon, and hydrogen from the halocarbon group. ODS is further disclosed as GRI standards indicators 305-6 or G4 Guidelines for indicators G4-EN20 in sustainability reports. In Table 1, we can see that the percentage of GRI indicator-based company disclosures related to ODS carbon emissions only amounted to $18.2 \%$ within the last 3 years. This data certainly proves that many companies, to date, have not paid enough attention to the issue, even though ODS has a significant impact on the environment.

\subsection{Comparison of Companies' Performances on Carbon Emission with Indonesia's Carbon Emission Reduction Targets}

The government of Indonesia has declared its commitment to reduce its Greenhouse Gas (GHG) emissions by $26 \%$ (on its own) and by $41 \%$ (with the addition of international assistance) by 2020 at the $15^{\text {th }}$ Conference of Parties (COP) in 2009. This was stated through President Regulations No. 61 of 2011 concerning National Action Plan for Reducing Greenhouse Gas Emissions (RAN-GRK). Indonesia's commitment is reinforced through the document Nationally Determined Contribution (NDC) of the Republic of Indonesia, the first implemented in November 2016, with the enactment of unconditional targets by $29 \%$ and the conditional targets of up to $41 \%$, compared to a business-as-usual scenario (BAU) in 2030 (Regulations No. 16 of 2016 concerning the Ratification of the Paris Agreement to the United Nations Framework Convention on Climate Change). On a national scale, the target of emission reduction in 2030, based on the NDC, amounts to 834 million tons of $\mathrm{CO}_{2}$ eq for the unconditional target, and 1,081 million tons of $\mathrm{CO}_{2}$ eq on the conditional target. To meet these targets, various mitigation actions have been carried out nationally in all sectors by parties responsible for mitigation actions.

Based on the results this research, there were only two companies who had published GRI disclosure topics related to reducing emissions (GRI Standards indicator 305-5 or G4 Guidelines indicator G4-EN19). This was done by stating the targeted emission reduction figure in accordance with the targets set up on the national scale. It was found that one of the 
companies has successfully exceeded the target, while the other company had nearly reached the National reduction target in 2018. Although it is difficult to generalise, due to the fact that not all companies produce disclosures using comparisons of national emission reduction targets, the results obtained from the two companies indicate that there have been several Indonesian companies in the mining \& mineral and oil \& gas sectors that have also pursued these national emission reduction targets and almost reached it.

\section{Conclusion}

One of the main causes of air pollution is carbon emissions. Increasing demands from stakeholders pushes disclosures of carbon emissions a matter of materiality to report on the company's sustainability reports. In measuring companies' performances in carbon emissions in the fields of Mining \& Mineral and Oil \& Gas, the basis of GRI indicators were used: aspects of emissions (6 pieces), energy ( 2 pieces), general disclosure ( 2 pieces), and economic performance (1 piece). Within the last three years, companies' performances in carbon emissions have generally shown good results, with a trend of decreased emissions. However, for the next period, companies will have to suppress $\mathrm{CO}_{2}$ emissions even more optimally, and pay a more focused attention to emissions related to Ozone Depleting Substances (ODS). When comparing companies' performances with national targets, there has been substantially positive results, as the rate of emissions reduction is already close to the target. Therefore, it can be concluded that the performances of Indonesian companies in the field of Mining and Mineral and Oil and Gas during 2016-2018 related to carbon emissions, in general has been positive, both in terms of sustainability reporting disclosures, as well as in terms of companies' performances in reducing and creating efficiencies in carbon emissions.

\section{References}

[1] Wahid, A. B., "detikNews," 28 July 2019. [Online]. Available: https://news.detik.com/berita/d4642349/airvisual-akhir-pekan-udara-jakarta-kembali-jadi-terburuk-di-dunia.

[2] Samosir, H. A. , "CNN Indonesia," 21 May 2015. [Online]. Available: https://www.cnnindonesia.com/gaya-hidup/20150521141419-255-54787/polusi-udara-sebabkanhampir-60-persen-penyakit-di-jakarta.

[3] Mantalean, V., "Kompas.com," 9 July 2019. [Online]. Available: https://megapolitan.kompas.com/read/2019/07/09/05322231/kpbb-dampak-polusi-udara-warga-dkirugi-rp-512-triliun.

[4] CNN Indonesia, "CNN Indonesia," 17 July 2019. [Online]. Available: https://www.cnnindonesia.com/nasional/20190716161616-20-412627/walhi-10-pltu-batu-barasumbang-30-persen-polusi-jakarta.

[5] Bisnis.com, "Bisnis.com," 8 May 2018. [Online]. Available: https://ekonomi.bisnis.com/read/20180508/44/792793/setahun-batu-bara-picu-20.000-kasuskematian-dini-.

[6] Okefinance, "okefinance," 10 May 2018. [Online]. Available: https://economy.okezone.com/read/2018/05/10/320/1896803/favor-batu-bara-tidak-banding-rusakenvironment.

[7] M. Anggilia and A. Djazuli, "An Overview: Forest Carbon Accounting (Case Study Ulu Masen Ecosystem Aceh Province, Indonesia)," TAZKIA Islamic Business and Finance Review, pp. 20-35. 
[8] R. Matineau and J.-P. Lafontaine, "When carbon accounting systems make us forget nature: from commodification to reification," Sustainability Accounting, Management and Policy Journal, 2018.

[9] A. Q. Al-Amin, A. H. Jaafar and C. Siwar, "Climate change mitigation and policy concern for prioritization," International Journal of Climate Change Strategies and Management, pp. 418-425, 2010 .

[10] M. Ja'far and L. Kartikasari, "Need Assesments: Standar Akuntansi Carbon," 2009.

[11] D. Guntari and K. Yunita, "Pengungkapan Emisi Karbon: Studi pada Perusahaan Manufaktur di Indonesia".

[12] U. Hanifah and Wahyono, "Diskursus Urgensi Carbon Emission Disclosure Pada PerusahaanPerusahaan Publik di Indonesia," Jurnal Penelitian , pp. 111-136, 2018.

[13] H. Hashim, M. Ramlan and Y. Wang, A New Framework for Carbon Accounting and Mitigation for Greening the Industry, Malaysia Sustainable Cities Program, Working Paper Series, 2017.

[14] F. Bowen and B. Wittneben, "Carbon accounting - Negotiationg accuracy, consistency and certainty across organisational fields," Accounting, Auditing \& Accountability Journal, pp. 1022-1036, 2011.

[15] J. Lash and F. Wellington, "Competitive advantage on a warming planet," Harvard Business Review, vol. 85, no. 3, pp. 94-102, 2007.

[16] D. N. Pratiwi, "Implementasi Carbon Emission Disclosure di Indonesia," Jurnal Ilmiah Akuntansi dan Bisnis , pp. 101-112, 2018.

[17] S. Berthelot and A. Robert, "Climate Change Disclosure: An Examination Of Canadanian Oil and Gas Firms," Issues In Social and Environmental Accounting, vol. 5, no. 1, pp. 106-123, 2011.

[18] A. Liesen, A. G. Hoepner, D. M. Patten and F. Figge, "Does stakeholder pressure influence corporate GHG emissions reporting? Empirical evidence from Europe," Accounting, Auditing \& Accountability Journal, 2015.

[19] B. Irwhantoko, "Carbon Emission Disclosure: Studi pada Perusahaan Manufaktur Indonesia," Jurnal Akuntansi dan Keuangan, pp. 92-104, 2016.

[20] J. Susilo, "Penerapan Carbon Offset Policy Sebagai Bagian dari CSR Perusahaan Melalui Carbon Accounting," APLIKASI BISNIS, pp. 1123-1135, 2008.

[21] P. F. Dwijayanti S., "Manfaat Penerapan Carbon Accounting di Indonesia," Jurnal Akuntansi Kontemporer, pp. 79-92, 2011.

[22] D. Gibassier and S. Schaltegger, "Carbon management accounting and reporting in practice - A case study on converging emergent approaches," Sustainability Accounting, Management and Policy Journal, pp. 340-365, 2015.

[23] M. J. Milne and S. Grubnic, "Climate change accounting research: keeping it interesting and different," Accounting, Auditing \& Accountability Journal, pp. 948-977, 2011.

[24] M. Huelsenbeck, "Ocean-Based Food Security Threatened in a High CO2 World. A Ranking of Nations' Vulnerability to Climate Change and Ocean Acidification," oceana.org, 2012.

[25] U. Sekaran and R. Bougie, Research Method for Business - A Skill Building Approach 7th Edition, West Sussex: John Wiley \& Sons Ltd, 2016.

[26] W. L. Neumann, Social Research Methods. Qualitative and quantitative approaches, 2003.

[27] R. H. Gray, R. Kouhy and S. Lavers, "Corporate Social and Environmental Reporting: A Review Of The Literature And A Longitudinal Study Of UK Disclosure," Accounting, Auditing and Accounting Journal, vol. 8, no. 2, 1995. 